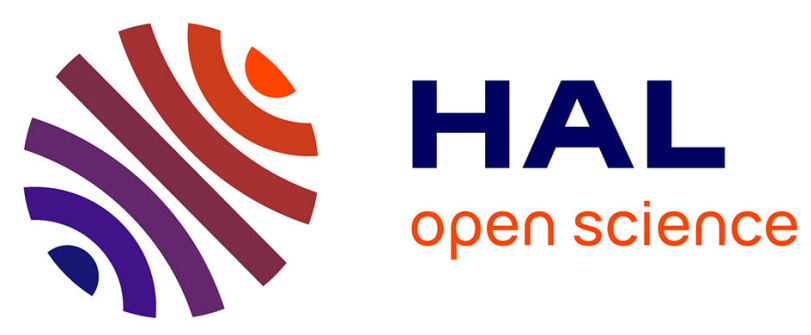

\title{
Hybrid sliding mode control of DFIG with MPPT using three multicellular converters
}

Fateh Taibi, Omar Benzineb, Mohamed Tadjine, M.S. Boucherit, Mohamed Benbouzid

\section{- To cite this version:}

Fateh Taibi, Omar Benzineb, Mohamed Tadjine, M.S. Boucherit, Mohamed Benbouzid. Hybrid sliding mode control of DFIG with MPPT using three multicellular converters. IFAC World Congress 2014, Aug 2014, Cape Town, South Africa. pp.11659-11666. hal-01063633

\section{HAL Id: hal-01063633 \\ https://hal.science/hal-01063633}

Submitted on 12 Sep 2014

HAL is a multi-disciplinary open access archive for the deposit and dissemination of scientific research documents, whether they are published or not. The documents may come from teaching and research institutions in France or abroad, or from public or private research centers.
L'archive ouverte pluridisciplinaire HAL, est destinée au dépôt et à la diffusion de documents scientifiques de niveau recherche, publiés ou non, émanant des établissements d'enseignement et de recherche français ou étrangers, des laboratoires publics ou privés. 


\title{
Hybrid Sliding Mode Control of DFIG with MPPT Using Three Multicellular Converters
}

\author{
F. Taibi*. O. Benzineb**. M. Tadjine*. M.S. Boucherit*. M.E.H. Benbouzid*** \\ *Ecole Nationale Polytechnique, Algiers Algeria \\ (e-mail:taibi.fateh@gmail.com,ms.boucherit@enp.edu.dz,mohamed.tadjine@enp.edu.dz). \\ **University of Blida, Blida,Algeria (e-mail:omar_benzineb@yahoo.fr) \\ ***University of Brest, Brest, France (e-mail: Mohamed.Benbouzid@univ-brest.fr)
}

\begin{abstract}
This paper deals with hybrid sliding mode control of Doubly Fed Induction Generator DFIG with Maximum Power Point Tracking MPPT connected by rotor side to three bridges of Multicellular Converters MCCs. The hybrid aspect of the converters is taken into consideration which includes the continuous and discrete states of the converters. The vector control is used to command the DFIG speed and reactive stator power. The currents in Park d-q reference are controlled using hybrid sliding mode. The sliding surfaces are developed using Lyapunov stability method. The developed controller allows decoupled control of the stator active and reactive power. The final results are illustrated at the end of this paper to present the advantages of the control method developed in this paper.
\end{abstract}

Keywords: multicellular converters, doubly fed induction generator, maximum power point tracking, vector control, hybrid system, sliding mode control.

\section{INTRODUCTION}

The earth is facing many problems regarding the environment, the climate and the global warming due to the intensive industries and the use of traditional sources of energy to provide power to people. The solutions for these problems are oriented toward the development of new clean, sustainable and environment friendly sources of energy; in which the solar and wind mostly known as renewable energy are well-placed. The production of energy from these natural resources has been developed enormously recently but is still remaining secondary in comparison with the existed power resources such as the hydrocarbon and nuclear. The common machines used as wind generator is the doubly fed induction generator (DFIG), Hansen et al. (2004), which is a wound rotor induction generator controlled by an inverter at the rotor terminals, Rothenhagen et al. (2009). The major advantages of the DFIG over traditional squirrel-cage induction generator are the operation in a higher wind speed range and production or consumption the reactive power through the magnetization provided by the rotor-side converter Dong et al. (2009). The power of the DFIG is managed and controlled by using power converters in order to control and stabilize the power provided to the grid. Wind Energy Conversion Systems are typical application cases where the efficient production is directly linked to economic benefits, Billinton et al. (2004), Koutroulis et al. (2006).

Among the power systems, multicellular converters are based on a series-association of elementary commutation cells. This structure, which appeared at the beginning of the 90's, allows sharing of voltage constraints by all commutation cells series- connected, which makes the waveform harmonic content greatly improved, Meynard et al. (2002).

In this paper, we study the modelling and control of the DFIG with MPPT by using three bridges of multicellular converters implemented in the rotor side and working in DC-AC conversion. The DFIG model including the electrical and mechanical equations is developed first in d-q reference, and then the model of multicellular converters is given accordingly in order to develop a global model representing the dynamics of the block DFIG with the converters. The resulting model is used after that to develop control law using vector and sliding mode control. The vector control is based on a stator reference oriented flux. We use in this paper the speed and reactive power control. The speed control generates the $\mathrm{d}-\mathrm{q}$ current references. The sliding mode controller is synthesized by respecting the hybrid nature of the converters in order to ensure the tracking of the DFIG d-q rotor currents to their references. In the same time, the floating voltages have to be maintained to guarantee the voltage balance, Gorp et al. (2011), Djemai et al. (2011). The simulation results are given at the end of this paper.

\section{MAXIMUM POWER POINT TRACKING (MPPT)}

The output energy of wind turbine depends on the method of tracking the peak power points on the turbine characteristics due to fluctuating wind conditions Abolhassani et al. (2008). From these methods, we have the MPPT method which allows to the turbine to work with a speed closed to its nominal value that permits the maximum power extraction. The expression of the mechanical power extracted from the 
wind energy is given as, Bekakra et al. (2001), Zheng et al. (2009).

$$
P_{m}=\frac{1}{2} C_{p} \rho S_{\omega} v^{3}
$$

Where $C_{p}$ is the wind turbine power conversion efficiency, $\rho$ is the air density, $S_{\omega}$ is the swept area of the turbine and $v$ is the speed of the wind.

The efficiency coefficient $C_{p}$ has a family of characteristics and is a function of the tip speed ratio $\lambda$ and the blade pitch angle $\beta$. For this work, we use the formula in (2) to calculate $C_{p}$, El Aimani, S. (2004).

$C_{P}=(0.5-0.167)(\beta-2) \sin \left(\frac{\pi(\lambda+0.1)}{18.5-0.3(\beta-2)}\right)-0.00184(\lambda-3)(\beta-2)$

In order to get the maximum mechanical energy from wind, this factor should be considered as its maximum value, Abolhassani et al. (2008). The speed ratio is the coefficient between the speeds of turbine and wind and can be expressed as

$$
\lambda=\frac{R \cdot \Omega_{t}}{v}
$$

$R$ is the length of turbine blade and $\Omega_{t}$ is the turbine speed.

The optimum value of the speed ratio is fixed in order to get the maximum value of the efficiency coefficient $C_{p}$.

Therefore the value of the mechanical power is fixed which gives the reference of the turbine speed to be controlled. The control efficiency of DFIG can be improved by adjusting the turbine speed as function of the wind speed; which allows reaching the maximum of the mechanical power.

For this application, an anemometer sensor is supposed to be used to measure the wind speed for the MPPT even it can cause a problem of uncertain measurements. The anemometer used to measure the wind speed represents a local measurement which is not representative of the mean value of the wind speed. It can be replaced by a speed estimator based on the turbine characteristics in order to get correct measurements. The electronic signals captured by the anemometer are used by the control system in order to start up the DFIG when the wind speed reaches approximately 5 $\mathrm{m} / \mathrm{s}$ but when the wind speed wind exceeds $25 \mathrm{~m} / \mathrm{s}$ the same control system will stop the DFIG to ensure the protection of the machine and the converters Gaillard, A., (2010).

\section{MODELING AND VECTOR CONTROL OF THE DFIG}

The DFIG brings the advantage of utilizing the turns ratio of the machine, so the converter does not need to be rated for the machine's full rated power. The DFIG structure consists of two converters, one is in the grid side called the grid side converter (GSC) and the other is in the machine side and called the rotor side converter (RSC). The GSC is an AC-DC converter used to maintain the voltage of the dc-link constant.
In the other hand, the RSC is connected to the DFIG to provide active and reactive power control of the machine (Fig. 1). The GSC can supply the required reactive current very quickly while the RSC passes the current through the machine resulting in a delay. Both converters can be temporarily overloaded, so the DFIG is able to provide a considerable contribution to grid voltage support during short circuit periods, Erlich et al. (2007).

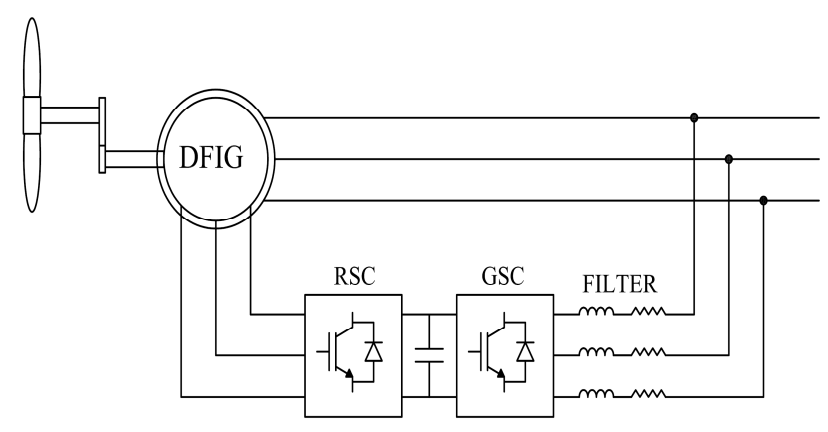

Fig. 1. Architecture of wind energy control system

\subsection{DFIG Model}

The classical modelling of the DFIG in the (d-q) Park reference frame, Gaillard et al. (2010); which included the stator and rotor fluxes, voltages current; is depicted in the electrical and mechanical equations.

$$
\left\{\begin{array}{l}
\frac{d}{d t} \varphi_{s d}=\omega_{s} \varphi_{s q}+V_{s d}-R_{s} I_{s d} \\
\frac{d}{d t} \varphi_{s q}=-\omega_{s} \varphi_{s d}+V_{s q}-R_{s} I_{s q} \\
\frac{d}{d t} \varphi_{r d}=\omega_{r} \varphi_{r q}+V_{r d}-R_{r} I_{r d} \\
\frac{d}{d t} \varphi_{r q}=-\omega_{r} \varphi_{r d}+V_{r q}-R_{r} I_{r q}
\end{array}\right.
$$

With

$$
\left\{\begin{array}{l}
\varphi_{s d}=L_{s} I_{s d}+M I_{r d} \\
\varphi_{s q}=L_{s} I_{s q}+M I_{r q} \\
\varphi_{r d}=L_{r} I_{r d}+M I_{s d} \\
\varphi_{r q}=L_{r} I_{r q}+M I_{s q}
\end{array}\right.
$$

Park's angles and speeds relative to rotor and stator variables and the DFIG speed $\omega$ are related as per (6):

$$
\theta_{s}=\theta+\theta_{r} \Rightarrow \omega_{s}=\omega+\omega_{r}
$$

The electromagnetic torque $T e$ is given including the stator flux and currents by:

$$
T e=p\left(\varphi_{s d} i_{s q}-\varphi_{s q} i_{s d}\right)
$$

The mechanical equation or the speed equation is as per the following equation:

$$
J \frac{d}{d t} \omega+f_{v} \omega=p(T e-T m)
$$


Where, $T m$ is the mechanical torque.

The DFIG is implemented and supplied by the grid power through the stator while the rotor is connected to the grid through two converters forming a double conversion alternative current $\mathrm{AC}$ to direct current $\mathrm{DC}$ and $\mathrm{DC}$ to $\mathrm{AC}$.

The multicellular converters consist of serial cells. Each cell contains two switches with complementary values. If one is closed the other is open and vice versa. These switches are controllable using control signal $u_{k}$. This signal $u_{k}$ is equal to 1 when the upper switch of the cell is conducting and 0 when the lower complementary switch of the cell is conducting Benzineb et al. (2011). It can be used for both DC-DC and DC-AC configurations. In this application, the multicellular converters are used to control the currents of the DFIG rotor. The RSC consists of three identical two cell converters implemented in parallel and power supplied by the dc-link voltage $E$ controlled by the grid side converter (GSC) (Fig. 2). In order to control the rotor currents in d-q plan, the basic model of the DFIG is developed in order to include the floating voltages and the converters switches.

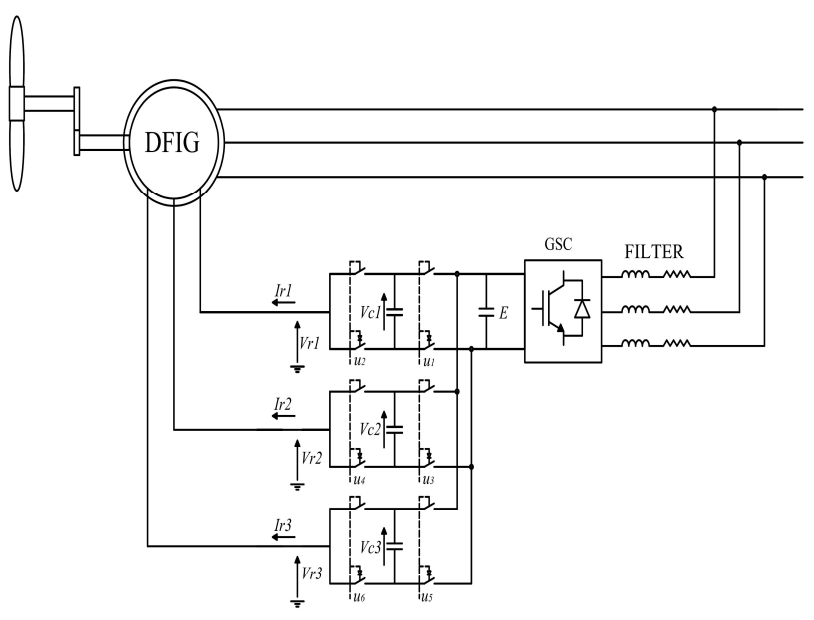

Fig. 2. Architecture of the block DFIG-MCCs

The relationships relating the floating voltages dynamics, the switches and the rotor currents $I_{r 1}, I_{r 2}$ and $I_{r 3}$ using Park transformation are given by, Gorp et al. (2011), Lienhardt et al. (2007).

$$
\left\{\begin{array}{l}
\frac{d V c_{1}}{d t}=\frac{1}{C_{1}}\left(u_{2}-u_{1}\right) \sqrt{\frac{2}{3}}\left(\cos \theta_{r} I r_{d}-\sin \theta_{r} I r_{q}\right) \\
\frac{d V c_{2}}{d t}=\frac{1}{C_{2}}\left(u_{4}-u_{3}\right) \sqrt{\frac{2}{3}}\left(\cos \left(\theta_{r}-\frac{2 \pi}{3}\right) I r_{d}-\sin \left(\theta_{r}-\frac{2 \pi}{3}\right) I r_{q}\right) \\
\frac{d V c_{3}}{d t}=\frac{1}{C_{3}}\left(u_{6}-u_{5}\right) \sqrt{\frac{2}{3}}\left(\cos \left(\theta_{r}+\frac{2 \pi}{3}\right) I r_{d}-\sin \left(\theta_{r}+\frac{2 \pi}{3}\right) I r_{q}\right)
\end{array}\right.
$$

The rotor voltages which represent the outputs of MCCs can be expressed in relation with the floating voltages as follows:

$$
\left\{\begin{array}{l}
V r_{1}=\left(u_{1}-u_{2}\right) V c_{1}+u_{2} E-E / 2 \\
V r_{2}=\left(u_{3}-u_{4}\right) V c_{2}+u_{4} E-E / 2 \\
V r_{3}=\left(u_{5}-u_{6}\right) V c_{3}+u_{6} E-E / 2
\end{array}\right.
$$

The term $E / 2$ is added to each rotor voltage to take into account the DC-AC functioning of the converters.

\subsection{Field Orientation}

The stator flux vector is used as reference in order to align it with the d-axis. The grid is assumed to be stable and consequently $\varphi_{s d}$ is constant, Gaillard et al. (2008). Based on the previous considerations, the following results can be deduced accordingly.

$$
\left\{\begin{array}{l}
\varphi_{s d}=\varphi_{s} \\
\varphi_{s q}=0
\end{array}\right.
$$

From a stable grid and constant stator flux assumption, we can write:

$$
\left\{\begin{array}{l}
V_{s d}=0 \\
V_{s q}=V_{s}=\omega_{s} \varphi_{s}
\end{array}\right.
$$

Then, the rotor voltages are given by:

$$
\left\{\begin{array}{l}
\frac{d I_{r d}}{d t}=-\frac{R r}{\sigma L_{r}} I_{r d}+\omega_{r} I_{r q}+\frac{1}{\sigma L_{r}} V_{r d} \\
\frac{d I_{r q}}{d t}=-\frac{R r}{\sigma L_{r}} I_{r q}-\omega_{r} I_{r d}+\frac{1}{\sigma L_{r}} V_{r q}-\frac{M \omega_{r}}{\sigma L_{r} L_{s} \omega_{s}} V_{s}
\end{array}\right.
$$

Where $\sigma$ is the dispersion coefficient and defined by:

$$
\sigma=1-\frac{M^{2}}{L_{r} L_{s}}
$$

In order to get a decoupled control between the direct and quadrature components of the rotor currents, the terms $\omega_{r} I_{r q}$. $-\omega_{r} I_{r q}$ and $-\frac{M \omega_{r}}{\sigma L_{r} L_{s} \omega_{s}} V_{s}$ have to be compensated by the controller.

Based on the precedent assumptions, the expressions of electromagnetic torque and stator reactive power are simplified and can be written in function of the rotor currents.

$$
\left\{\begin{array}{l}
T e=-\frac{p M}{L_{s}} \frac{V_{s}}{\omega_{s}} I_{r q} \\
Q_{s}=\frac{V_{s}^{2}}{L_{s} \omega_{s}}-\frac{V_{s} M}{L_{s}} I_{r d}
\end{array}\right.
$$

The rotor current references are generated by setting the electromagnetic and the stator reactive power references (Fig. 3).

The speed control aims to regulate the electromagnetic torque of the DFIG shaft in order to fix it. To achieve that, a speed control is applied to the DFIG.

The rotation speed is controlled by using a PI controller in order to reach the speed reference $\omega^{*}$ defined by MPPT algorithm. The speed reference $\omega^{*}$ can be given using (3) by fixing the optimum value of the speed ratio in order to get the maximum value of the efficiency coefficient. 
From that, we can get the reference value of the electromagnetic torque to orient the stator flux.

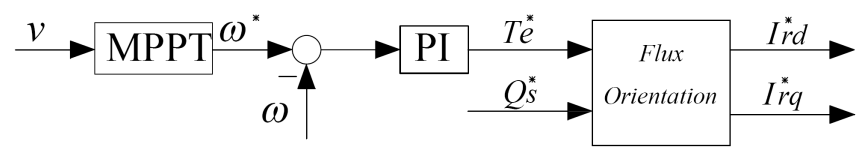

Fig. 3. Generation of rotor current references using MPPT

From (15), the reference values of rotor currents can be gotten as follows:

$$
\left\{\begin{array}{l}
I_{r d}^{*}=-\frac{L_{s}}{M} \frac{Q_{s}^{*}}{V_{s}}+\frac{V_{s}}{M \omega_{s}} \\
I_{r q}^{*}=-\frac{L_{s}}{p M} \frac{\omega_{s}}{V_{s}} T e^{*}
\end{array}\right.
$$

Where, $T e^{*}$ and $Q_{s}^{*}$ are the desired values of electromagnetic torque and stator reactive power to be maintained by the control system.

\subsection{Control of the Grid Side Converter}

The GSC is used to regulate the voltage of the dc-link connected between the RSC and the GSC, Gaillard et al. (2008).

PWM control is used to control the grid filter d-q currents. A PI controller is implemented to control the dc-link voltage in which we need the expression of the current to feed the multicellular converters. The expression is given by

$$
I_{\text {conv }}=u_{1} I_{r 1}+u_{3} I_{r 2}+u_{5} I_{r 3}
$$

The grid current $I_{\text {grid }}$ passes through the grid filter in order to feed the dc-link $E$, which supplies the multicellular converters with the current $I_{c o}$

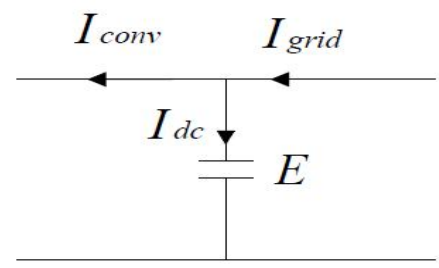

Fig. 4. The multicellular converters current input

\section{CONTROL OF THE BLOCK DFIG-MCCs USING SLIDING MODE CONTROL}

In order to control the DFIG through the multicellular converters, we have to get the combined model of the two systems. This cannot be achieved without using the characteristics of Park transformation. The combination of an hybrid model of the multicellular converters and a continuous model of the DFIG results a hybrid model where the voltages and currents are the continuous variables and the power switches are the discontinuous variables.

\subsection{Global Model}

The rotor voltages can be written using Park transformation as follows:

$$
\left\{\begin{array}{l}
V r_{d}=\sqrt{\frac{2}{3}}\left(\cos \theta_{r} V r_{1}+\cos \left(\theta_{r}-\frac{2 \pi}{3}\right) V r_{2}+\cos \left(\theta_{r}+\frac{2 \pi}{3}\right) V r_{3}\right) \\
V r_{q}=-\sqrt{\frac{2}{3}}\left(\sin \theta_{r} V r_{1}+\sin \left(\theta_{r}-\frac{2 \pi}{3}\right) V r_{2}+\sin \left(\theta_{r}+\frac{2 \pi}{3}\right) V r_{3}\right)
\end{array}\right.
$$

By combining (9), (10), (13) and (18), the expression of rotor voltages $V r_{d}$ and $V r_{q}$ is developed and can be implemented in

(19) to get the dynamics of each MCC taking into account the dynamics of the rotor currents in d-q plan. The global model of the block DFIG-MCCs is described by

$$
\begin{aligned}
& \left\{\begin{aligned}
\frac{d V c_{1}}{d t}= & \frac{1}{C_{1}} \sqrt{\frac{2}{3}}\left(\cos \left(\theta_{r}-\theta_{1}\right) I r_{d}-\sin \left(\theta_{r}-\theta_{1}\right) I r_{q}\right)\left(u_{2}-u_{1}\right) \\
\frac{d V c_{2}}{d t}= & \frac{1}{C_{2}} \sqrt{\frac{2}{3}}\left(\cos \left(\theta_{r}-\theta_{2}\right) I r_{d}-\sin \left(\theta_{r}-\theta_{2}\right) I r_{q}\right)\left(u_{4}-u_{3}\right) \\
\frac{d V c_{3}}{d t}= & \frac{1}{C_{3}} \sqrt{\frac{2}{3}}\left(\cos \left(\theta_{r}-\theta_{3}\right) I r_{d}-\sin \left(\theta_{r}-\theta_{3}\right) I r_{q}\right)\left(u_{6}-u_{5}\right) \\
\frac{d I_{r d}}{d t}= & -\frac{R_{r}}{\sigma L_{r}} I_{r d}+\omega_{r} I_{r q}+\frac{1}{\sigma L_{r}} \sqrt{\frac{2}{3}} \sum_{i} \cos \left(\theta_{r}-\theta_{i}\right)\left(V c_{i} u_{2 i-1}+u_{2 i}\left(E-V c_{i}\right)\right) \\
\frac{d I_{r q}}{d t}= & -\frac{R_{r}}{\sigma L_{r}} I_{r q}-\omega_{r} I_{r d}-\frac{1}{\sigma L_{r}} \sqrt{\frac{2}{3}} \sum_{i} \sin \left(\theta_{r}-\theta_{i}\right)\left(V c_{i} u_{2 i-1}+u_{2 i}\left(E-V c_{i}\right)\right) \\
& -\frac{M \omega_{r}}{\sigma L_{r} L_{s} \omega_{s}} V_{s}
\end{aligned}\right. \\
& \text { Where } \theta_{i}=(i-1) \frac{2 \pi}{3} \text { and } i=1,3
\end{aligned}
$$

We use the formulas in (20) to simplify the equations:

$$
\left\{\begin{array}{l}
\cos \left(\theta_{i}\right)+\cos \left(\theta_{i}-\frac{2 \pi}{3}\right)+\cos \left(\theta_{i}+\frac{2 \pi}{3}\right)=0 \\
\sin \left(\theta_{i}\right)+\sin \left(\theta_{i}-\frac{2 \pi}{3}\right)+\sin \left(\theta_{i}+\frac{2 \pi}{3}\right)=0
\end{array}\right.
$$

According to the global model in (19), the control switches of each converter $\left\{u_{2 i-1}, u_{2 i}\right\}, i=1,3$ don't interfere on the other converters floating voltage dynamics. In order to get an independent control synthesis for each converter, we suppose that the control switches of each converter $\left\{u_{2 i-1}, u_{2 i}\right\}, i=1,3$ don't interfere also on the other converters output current dynamics. We get then three independent subsystems given by.

$$
\left\{\begin{aligned}
\frac{d V c_{i}}{d t}= & \frac{1}{C_{i}} \sqrt{\frac{2}{3}}\left(\cos \left(\theta_{r}-\theta_{i}\right) I r_{d}-\sin \left(\theta_{r}-\theta_{i}\right) I r_{q}\right)\left(u_{2 i}-u_{2 i-1}\right) \\
\frac{d I_{r d}}{d t}= & -\frac{R_{r}}{\sigma L_{r}} I_{r d}+\omega_{r} I_{r q}+\frac{1}{\sigma L_{r}} \sqrt{\frac{2}{3}} \cos \left(\theta_{r}-\theta_{i}\right)\left(V c_{i} u_{2 i-1}+u_{2 i}\left(E-V c_{i}\right)\right) \\
\frac{d I_{r q}}{d t}= & -\frac{R_{r}}{\sigma L_{r}} I_{r q}-\omega_{r} I_{r d}-\frac{1}{\sigma L_{r}} \sqrt{\frac{2}{3}} \sin \left(\theta_{r}-\theta_{i}\right)\left(V c_{i} u_{2 i-1}+u_{2 i}\left(E-V c_{i}\right)\right) \\
& -\frac{M \omega_{r}}{\sigma L_{r} L_{s} \omega_{s}} V_{s}
\end{aligned}\right.
$$

Where $\theta_{i}=(i-1) \frac{2 \pi}{3}$ and $i=1,3$ 
The stator reference oriented flux vector control with sliding mode control of the RSC of DFIG is schematized in (fig. 5) The RSC control system presented here is established from the equations of the DFIG and multicellular converters models.

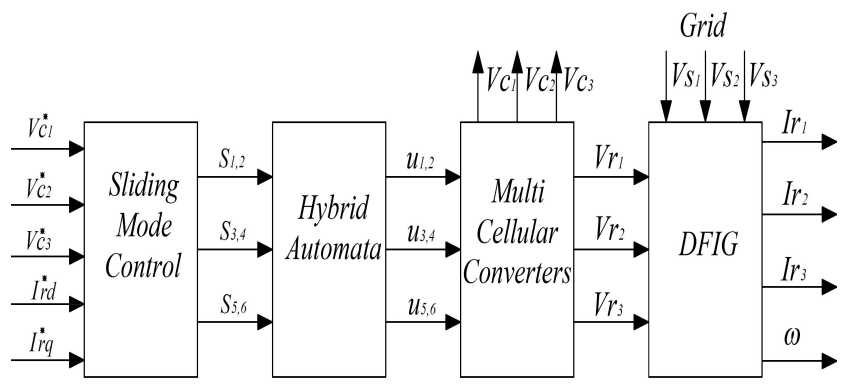

Fig. 5. Oriented flux hybrid sliding mode control of DFIG

The traditional classic PI controllers of the d-q rotor currents are replaced by a sliding mode controller. The aim of this controller is to regulate the $\mathrm{d}-\mathrm{q}$ currents and the floating voltages represented in (Fig. 5) by their references $V c_{1}{ }^{*}, V c_{2}{ }^{*}, V c_{3}{ }^{*}, I_{r d}{ }^{*}$ and $I_{r q}{ }^{*}$. The controller will generate the sliding functions which have to be around the origin in order to satisfy the stability criteria of the global system. These functions are used to generate the control input to the converters through hybrid automata.

\subsection{Synthesis of Sliding Functions}

The aim of the control is to regulate the d-q rotor currents and the floating voltages. The references of the floating voltages $V c_{i}{ }^{*}$ have to be equal or around the half value of the power supply $E$ in order to satisfy the natural balancing $V c_{i}{ }^{*}=\frac{E}{2}$, Wilkinson et al. (2006). By using Lyapunov method for the synthesis of the sliding functions, the tracking error is defined as:

$$
\Delta x^{T}=\left[\begin{array}{ll}
V c_{i}-V c_{i}^{*} & I_{r d}-I_{r d}^{*} \quad I_{r q}-I_{r q}^{*}
\end{array}\right]
$$

Lyapunov function is defined as:

$$
V(\Delta x)=\frac{1}{2}\left(C_{i}\left(V c_{i}-V c_{i}^{*}\right)^{2}+\sigma L_{r}\left(I_{r d}-I_{r d}^{*}\right)^{2}+\sigma L_{r}\left(I_{r q}-I_{r q}^{*}\right)^{2}\right)
$$

If $\Delta x=0$ then $V(0)=0$

Let us consider the sliding functions $S_{2 i-1}$ and $S_{2 i}$, $i=1,3$ where:

$$
\left\{\begin{aligned}
S_{2 i-1} & =V c_{i}\left(\cos \left(\theta_{r}-\theta_{i}\right) I_{r d}{ }^{*}-\sin \left(\theta_{r}-\theta_{i}\right) I_{r q}{ }^{*}\right) \\
& -V c_{i}^{*}\left(\cos \left(\theta_{r}-\theta_{i}\right) I_{r d}-\sin \left(\theta_{r}-\theta_{i}\right) I_{r q}\right) \\
S_{2 i} & =\left(E-V c_{i}\right)\left(\cos \left(\theta_{r}-\theta_{i}\right) I_{r d}{ }^{*}-\sin \left(\theta_{r}-\theta_{i}\right) I_{r q}{ }^{*}\right) \\
& -V c_{i}^{*}\left(\cos \left(\theta_{r}-\theta_{i}\right) I_{r d}-\sin \left(\theta_{r}-\theta_{i}\right) I_{r q}\right)
\end{aligned}\right.
$$

We can notice that if $V c_{i}=V c_{i}{ }^{*}, I_{r d}=I_{r d}{ }^{*}, I_{r q}=I_{r q}{ }^{*}$ then $S_{2 i-1}=0, S_{2 i}=0 \quad i=1,3$
The derivative of Lyapunov function is given by:

$$
\begin{aligned}
\dot{V}= & -R_{r} I_{r d}{ }^{2}-R_{r} I_{r q}{ }^{2}+\omega_{r} \sigma L_{r} I_{r q}{ }^{*} I_{r d}-\left(\omega_{r} \sigma L_{r} I_{r d}{ }^{*}+\frac{M \omega_{r}}{L_{s} \omega_{s}} V_{s}\right) I_{r q} \\
& +\frac{M \omega_{r}}{L_{s} \omega_{s}} V_{s} I_{r q}{ }^{*}+\sqrt{\frac{2}{3}} S_{2 i-1} u_{2 i-1}+\sqrt{\frac{2}{3}} S_{2 i} u_{2 i}
\end{aligned}
$$

The derivative has to be negative in order to ensure the stability of the closed system. The control vector can be divided into two terms: the equivalent control and the vector representing the effective control.

$$
\left\{\begin{array}{l}
u_{2 i-1}=U_{2 i-1}^{e q}+u_{2 i-1}^{*} \\
u_{2 i}=U_{2 i}^{e q}+u_{2 i}^{*}
\end{array}\right.
$$

Where $U_{2 i-1}^{e q}, U_{2 i}^{e q}$ and $u_{2 i-1}^{*}, u_{2 i}^{*}$ are the equivalent and the effective controls effectively.

The derivative function can be rewritten as:

$$
\begin{aligned}
\dot{V}= & -R_{r} I_{r d}{ }^{2}-R_{r} I_{r q}{ }^{2}+\omega_{r} \sigma L_{r} I_{r q}{ }^{*} I_{r d}-\left(\omega_{r} \sigma L_{r} I_{r d}{ }^{*}+\frac{M \omega_{r}}{L_{s} \omega_{s}} V_{s}\right) I_{r q} \\
& +\frac{M \omega_{r}}{L_{s} \omega_{s}} V_{s} I_{r q}{ }^{*}+\sqrt{\frac{2}{3}} S_{2 i-1} U_{2 i-1}^{e q}+\sqrt{\frac{2}{3}} S_{2 i} U_{2 i}^{e q}+\sqrt{\frac{2}{3}} S_{2 i-1} u_{2 i-1}^{*}+\sqrt{\frac{2}{3}} S_{2 i} u_{2 i}^{*}
\end{aligned}
$$

When the converter is controlled in opened loop, the grander of the control is constant; which means $u=U^{e q}$ and $u^{*}=0$. In this case, the derivative of Lyapunov function is independent of the control. And because of the resistive elements, the value of Lyapunov function is always negative.

The terms $-R_{r} I_{r d}{ }^{2}-R_{r} I_{r q}{ }^{2}$ are always negative.

This term $\omega_{r} \sigma L_{r} I_{r q}{ }^{*} I_{r d}-\left(\omega_{r} \sigma L_{r} I_{r d}{ }^{*}+\frac{M \omega_{r}}{L_{s} \omega_{s}} V s\right) I_{r q}+\frac{M \omega_{r}}{L_{s} \omega_{s}} V_{S} I_{r q}{ }^{*}$, which represents the expression of decoupling terms in the DFIG model is also negative.

When the converters start to work in closed loop, the equivalent control will compensate the value of these terms in the derivative of Lyapunov function; which means that in order to have negative derivative function the remaining expression $S_{2 i-1} u_{2 i-1}^{*}+S_{2 i} u_{2 i}^{*}$ has to be negative. This can be respected only and only

If $u_{2 i-1}^{*}, u_{2 i}^{*}<0$ then $S_{2 i-1}, S_{2 i}>0$ respectively.

And if $u_{2 i-1}^{*}, u_{2 i}^{*}>0$ then $S_{2 i-1}, S_{2 i}<0$ respectively.

The effective control $u_{2 i-1}{ }^{*}$ and $u_{2 i}{ }^{*}$ can only have two values 0 or 1, then (Benzineb et al. (2011), Benmansour et al. (2007)).

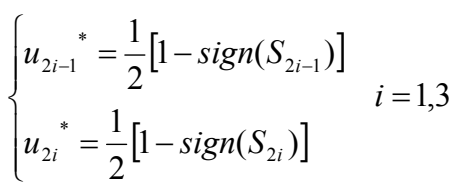


Hence, one can conclude that the derivative of Lyapunov function $\dot{V}$ is negative. The asymptotic stability is therefore guaranteed using the sliding mode control.

Equation 27 shows that depending on the sign of the sliding functions, the state of the discrete control is defined. We use these functions to write the transition conditions. We can get the maximum of the transitions if all conditions of the sliding functions are considered. However in order to respect the adjacency principle of the switches in the power converters; that means only one interrupter can change its state at a time, some of the transitions cannot be considered. A hybrid sliding mode control automata of the first converter is proposed in order to take into consideration this adjacency principle and illustrated in (Fig. 6). The same automata is applied for the second and third converters. The control aim is to make the sliding surfaces converging to the origin, which therefore allows to the state variables to reach their references.

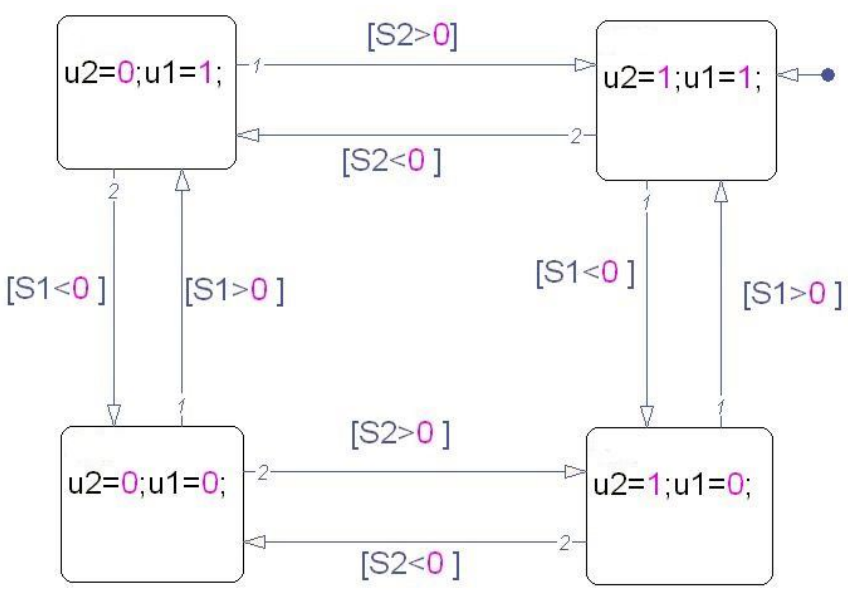

Fig. 6. Simulink-Stateflow automata for hybrid sliding mode control of one multicellular converter

The other two converters will have the same automata with their corresponding control switches and sliding functions. The stability of the DFIG controlled by the multicellular converters depends also on the stability of the speed control, dc-link of GSC stability and the Grid stability.

\section{SIMULATION RESULTS}

In this paper, we have conducted the study of two cells converters. The same study can be applied for multicellular converters with high number of cells.

In order to validate the previous results and evaluate the control strategy, the synthesized controller is applied to control the mechanical speed, the reactive stator power and the floating voltages. MATLAB is used to carry out the simulation.

A step change is applied to the wind speed starting from 4 $\mathrm{m} / \mathrm{s}$ and changing to $6 \mathrm{~m} / \mathrm{s}$ at instant 1 second. For the stator reactive power, the reference is equal to $0 \mathrm{~V} \cdot \mathrm{A} \cdot \mathrm{R}$.
Fig. 8 illustrates the turbine speed. We can observe that the turbine speed follows the change in the wind speed according to MPPT algorithm. A non zero steady state error is present because of the small value of the integrator parameter in the speed controller which was chosen to avoid oscillations in the speed curve.

Fig. 9 and 10 show the stator active and reactive power. The regulation is well-done. The reactive power is maintained to zero, to guarantee a unity power factor at the stator side. The value of the stator active power follows the turbine speed according to (15) seeing that the electromagnetic torque is the image of the stator active power.

Fig. 11 and 12 illustrate the floating voltages and the sliding functions. During the transient response, the floating capacitors start charging until the value of their voltages is equal to half of the converters power supply $E$.

We notice the sliding functions to converge to zero. At time 1 second, when there is a change in wind speed, the synthesised control law shows its robustness regarding this change and compensate its value without affecting the control of the floating voltages. This guarantees a balanced contribution of the floating voltages which flow always around their references.

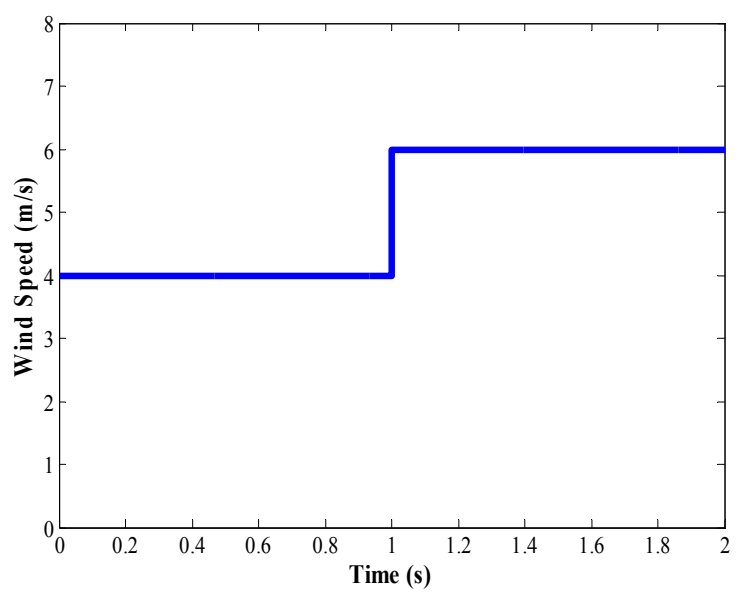

Fig. 7. Wind speed with a step change

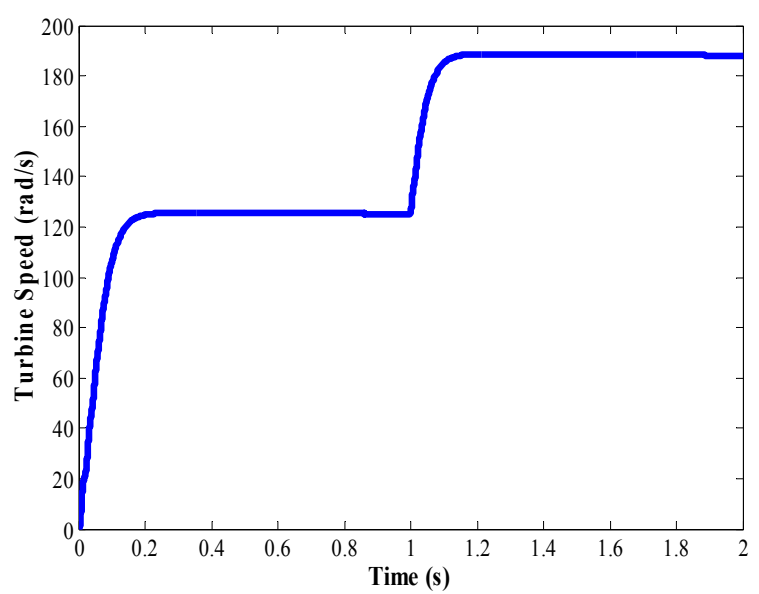

Fig. 8. Turbine speed by using MPPT 


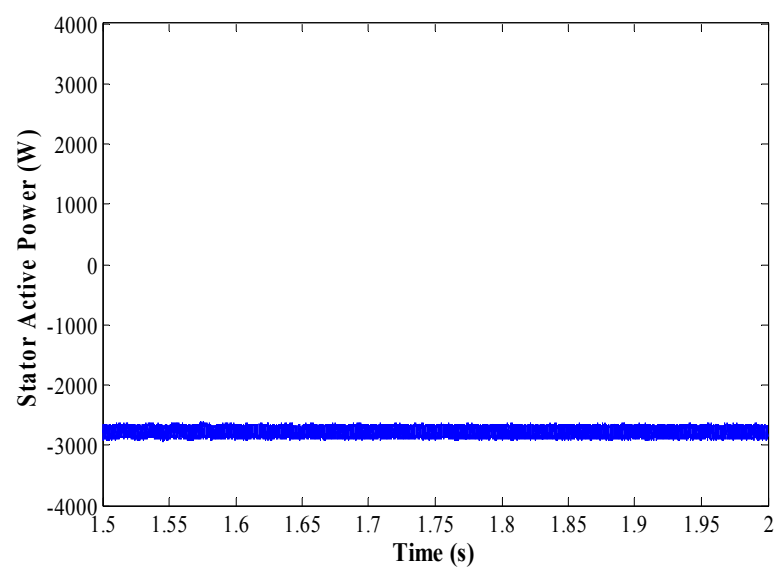

Fig. 9. Stator active power

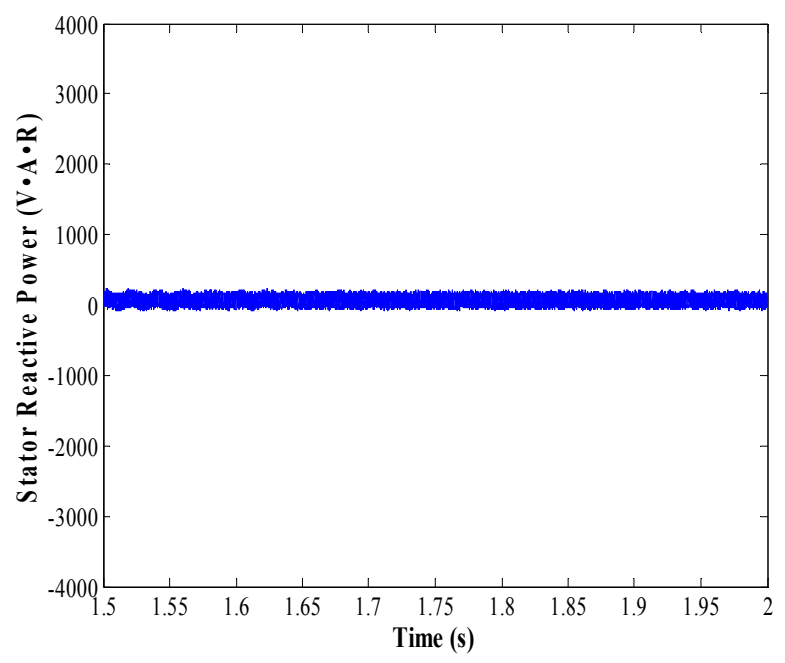

Fig. 10. Stator reactive power

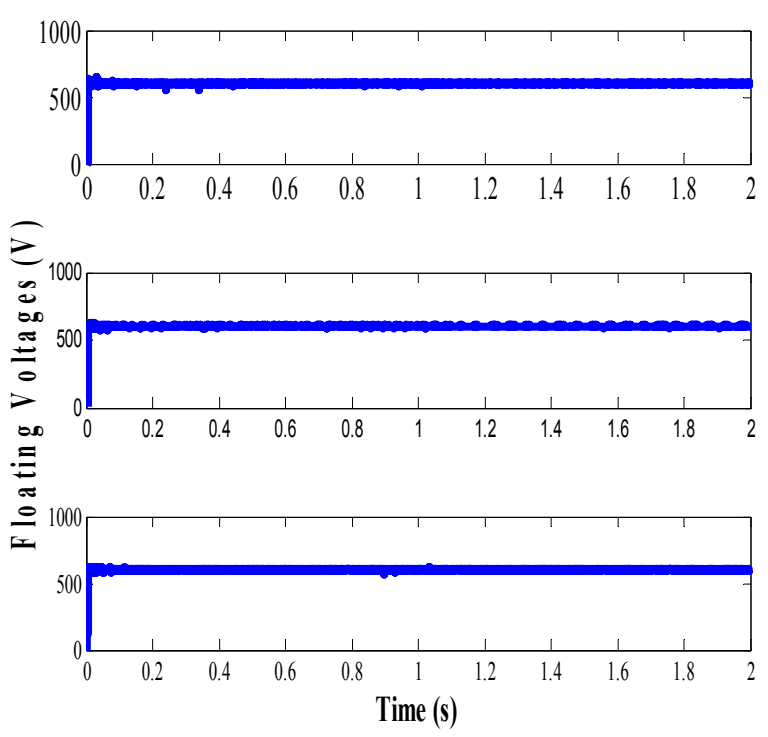

Fig. 11. Floating voltages

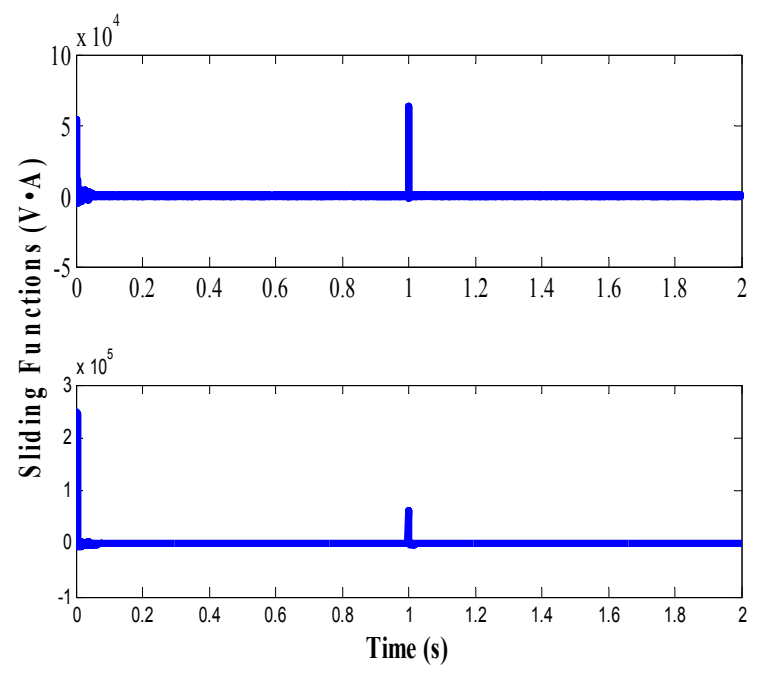

Fig. 12. Sliding functions

\section{CONCLUSION}

In this paper, a hybrid sliding mode controller is designed for the DFIG connected in the rotor side by multicellular converters. The controller based on Lyapunov function and hybrid automata has been developed. The control strategy is capable of controlling the turbine speed by capturing the maximum of wind power using the MPPT approach and controlling the stator reactive power. The simulation results have shown the efficiency of the proposed controller.

\section{REFERENCES}

Abolhassani, M.T., Enjeti, P. and Toliyat, H., (2008). Integrated Doubly Fed Electric Alternator/Active Filter (IDEA), a Viable Power Quality Solution, for Wind Energy Conversion Systems. IEEE TRANSACTIONS ON ENERGY CONVERSION, volume (23), no. 2.

Bekakra, Y. and Benattous, D., (2001). Active and Reactive Power Control of a DFIG with MPPT for Variable Speed Wind Energy Conversion using Sliding Mode Control. World Academy of Science, Engineering and Technology 60, 1543-1549.

Benmansour, K., Benalia, A., Djemaï, M. and de Leon, J., (2007). Hybrid control of a multicellular converter. Nonlinear Analysis: Hybrid Systems, volume (1), no.1, 16-19.

Benzineb, O., Taibi, F., Boucherit, M.S., Tadjine, M. and Benbouzid, M.E.D, (2011). Multicell Converters Hybrid Sliding Mode Control. International Review on Modelling and Simulations 4, 4 (2011) 1396-1403.

Billinton, R. and Bai, G., (2004). Generating capacity adequacy associated with wind energy", IEEE transactions on energy conversion, volume (19), 641-646

Djemai M., Busawon K., Benmansour K. and Marouf A., (2011). High order sliding mode control of a DC motor via a switched controlled multicellular converter. Int. J. of Systems Science.

Dong, B., Asgarpoor, S. and Qiao, W., (2009). Voltage Analysis of Distribution Systems with DFIG Wind 
Turbines. IEEE Power Electronics and Machines in Wind Applications, 1.

El Aimani, S., (2004). Modélisation de différentes technologies d'éoliennes intégrées dans un réseau de moyenne tension. $\mathrm{PhD}$ thesis Ecole Centrale de Lille, Lille, France.

Erlich, I., Wilch, M. and Feltes, C., (2007). Reactive Power Generation by DFIG Based Wind Farms with AC Grid Connection. University of Duisburg-Essen, 47057 Duisburg, Germany.

Gaillard, A. and Saadate, S., (2008). Active Filtering Capability of WECS with DFIG for Grid Power Quality Improvement. IEEE, 978-1-4244-1666-0/08.

Gaillard, A., (2010). Système éolien basé sur une MADA : contribution à l'étude de la qualité de l'énergie électrique et de la continuité de service. PhD thesis l'Université Henri Poincaré, Nancy-I, France.

Gorp, J.V., Defoort, M. and Djemai, M., (2011). Binary signals design to control a power converter. 50th IEEE Conference on Decision and Control and European Control Conference (CDC-ECC) Orlando, FL, USA, December 12-15.

Hansen, A.D., Iov, F. and Blaabjerg, F., and Hansen, L. H., (2004). Review of contemporary wind turbine concepts and their market penetration. J. Wind Eng., volume (28), no. 3, 247-263.

Koutroulis, E. and Kalaitzakis, K., (2006). Design of a maximum power tracking system for wind-energyconversion applications. IEEE transactions on industrial electronics, volume (53), 486-494

Lienhardt, A.M., Gateau, G. and Meynard, T., (2007). Digital sliding-mode observer implementation using FPGA. IEEE Trans. Industrial Electronics, volume (54), no. 4, 1865-1875.

Macken, K.J.P., Vanthournout, K., Van den Keybus, J., Deconinck, G. and Belmans, R.J.M., (2004). Distributed Control of Renewable Generation Units With Integrated Active Filter, IEEE TRANSACTIONS ON POWER ELECTRONICS, volume (19), no. 5.

Meynard, T.A., Foch, H., Thomas, P., Courault, J., Jakob, R. and Nahrstaedt, M., (2002). Multicell converters: basic concepts and industry applications. IEEE Trans. Industrial Electronics, volume (49), no. 5, 955-964.

Perry, T.S., (2001). Deregulation may give a boost to renewable resources. IEEE Spectrum, volume (38), 87.

Rothenhagen, K. and Fuchs, F.W., (2009). Current Sensor Fault Detection, Isolation, and Reconfiguration for Doubly Fed Induction Generators. IEEE TRANSACTIONS ON INDUSTRIAL ELECTRONICS, volume (56), no. 10, 1.

Zheng, X., Li, L., Xu, D. and Platts, J., (2009). Sliding mode MPPT control of variable speed wind power system. Power and Energy Engineering Conference, 1-4.

Wilkinson, R.H., Meynard, T.A. and du Toit Mouton, H., (2006). Natural balance of multicell converters: The general case. IEEE Trans. Power Electronics, volume (21), no. 6, 1658-1666.
Table 1. System Parameters

\begin{tabular}{|l|l|}
\hline System & Parameters \\
\hline Grid & $220 \mathrm{~V}$ \\
\hline & $R r=1.8 \Omega, R s=1.2 \Omega$ \\
& $L s=0.1554 \mathrm{H}, \mathrm{Lr}=0.1568 \mathrm{H}$ \\
DFIG & $J=0.325 \mathrm{~kg} \cdot \mathrm{m} 2, R=3 \mathrm{~m}$ \\
& $f v=0.00673 \mathrm{~N} \cdot \mathrm{m} / \mathrm{s}$ \\
& $p=2, M=0.15$ \\
\hline Multicellular & $E=1200 \mathrm{~V}, \quad C_{1}=40 \mu \cdot \mathrm{F} ;$ \\
Converters & $C_{2}=40 \mu \cdot \mathrm{F} ; C_{3}=40 \mu \cdot \mathrm{F} ;$ \\
\hline MPPT Control & $\beta=4, \lambda_{\text {opt }}=9.2$ \\
\hline
\end{tabular}

